\title{
Role of If (Funny Current) on Biological Pacemaker - Insight From A Ventricular Model
}

\author{
Yacong $\mathrm{Li}^{1}$, Kuanquan Wang ${ }^{1}$, Qince $\mathrm{Li}^{1}$, Xiangyun Bai ${ }^{1}$, Henggui Zhang ${ }^{1,2,3,4}$ \\ ${ }^{1}$ School of Computer Science and Technology, Harbin Institute of Technology, Harbin, China \\ ${ }^{2}$ School of Physics and Astronomy, the University of Manchester, Manchester, UK \\ ${ }^{3}$ Space Institute of Southern China (Shenzhen), Shenzhen, China \\ ${ }^{4}$ Key Laboratory of Medical Electrophysiology, Ministry of Education, Collaborative Innovation \\ Center for Prevention and Treatment of Cardiovascular Disease/Institute of Cardiovascular Research, \\ Southwest Medical University, Luzhou, China
}

\begin{abstract}
Biological pacemaker has been proposed as a promising alternative to electrical pacemaker for treating patients with impaired native cardiac pacemaker. It has been verified that overexpressing the hyperpolarizationactivated funny channel current (funny current, $I_{f}$ ) can induce automatic pacing activities in ventricular myocytes $(V M s)$. In this study, possible roles of $I_{f}$ expression in generating automaticity in VMs are systematically investigated. We implemented a computational approach to study mechanism by which increase of $I_{f}$ induces automaticity in VMs. The TP06 model of the electrical action potential in the human VMs was modified by incorporating $I_{f}$ formulation. When the channel conductance of $I_{f}$ was greater than $0.09 \mathrm{nS} / \mathrm{pF}$, the VMs showed spontaneous pacing activities. During the time course of spontaneous action potentials, incorporating $I_{f}$ induced changes in the intracellular ionic concentrations, leading to accumulation of intracellular calcium $\left(\left[\mathrm{Ca}^{2+}\right]_{i}\right)$ as well as sodium concentration $\left(\left[\mathrm{Na}^{+}\right]_{i}\right)$, but a decrease in the intracellular potassium concentration $\left(\left[\mathrm{K}^{+}\right]_{i}\right)$. By clamping $\left[\mathrm{Na}^{+}\right]_{i}$ and $\left[\mathrm{K}^{+}\right]_{i}$ to a constant level, a fast and stable spontaneous pacemaking activity was observed. This study helps to understand the mechanism of creating biological pacemakers using $I_{f}$ overexpression.
\end{abstract}

\section{Introduction}

Although electrical pacemaker has saved millions of lives since it was used clinically, plenty of patients could not benefit from electrical pacemaker due to its high risk of open-chest surgery and the complications of implanting device [1]. Biological pacemaker is an innovative therapy as a replacement of electrical pacemaker. By injecting pacemaker cells into certain regions of the heart, such as atrium or ventricle, biological pacemaker therapy is expected to induce the sinoatrial-node-like pacing activity in the injected region and then drive the whole heart. The first issue of this method is producing pacemaker cells.

Previous experiments showed that overexpressing hyperpolarization-activated current (funny current, $\mathrm{I}_{\mathrm{f}}$ ) in nonautomatic cardiac cells could induce spontaneous automaticity in cells $[2,3]$. Generally, there are three approaches to produce pacing cells: gene therapy, cell therapy and the hybrid therapy [1]. By gene therapy $\mathrm{I}_{\mathrm{f}}$ ionic channels are expressed in cardiac myocytes by fusing certain gene into cells. For instance, injecting hyperpolarization-activated cyclic nucleotide-gated 2 (HCN2) that codes the $\mathrm{I}_{\mathrm{f}}$ channel into canine left atrium [2] and left bundle-branch [3] via adenoviral constructs has successfully induced auto-rhythmicity in infected cells. Also, it has been shown that overexpressing $\mathrm{HCN} 2$ in two ventricular myocytes (VMs) system facilitated propagation of electrical signal from a HCN2-injected pacemaker cell to a quiescent cell [4]. With reprogramming the T-box 18 (TBX18), a kind of embryonic transcription factor related to the expression of $\mathrm{HCN}$ gene family in VMs, a superior gene therapy enabled the porcine heart to support normal heart rate and physical activity due to an increased $\mathrm{I}_{\mathrm{f}}$ [5]. That study, for the first time, demonstrated autorhythmic biopacemaker in big animal heart. Cell therapy guide stem cells to differentiate into cardiomyocytes with pacemaker activity and then infects pacing cells into certain cardiac region. Embryonic Stem Cells (ESCs) [6], Mesenchymal Stem Cells (MSCs) [7] and Adipose Derived Stem Cells (ADSCs) [8] are common targets that is used to produce 
$\boldsymbol{A}$
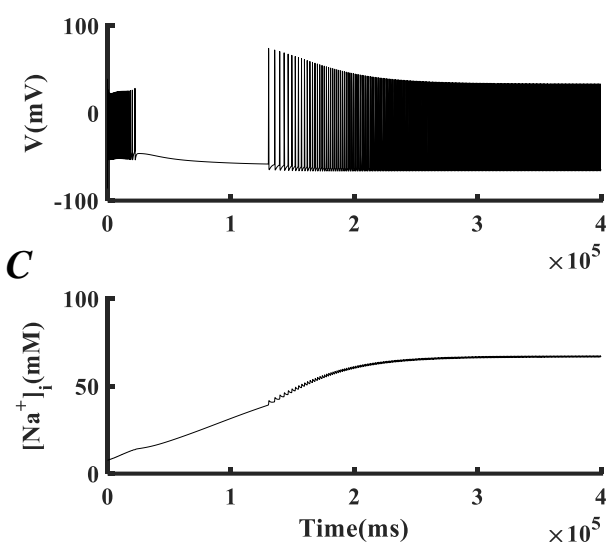

$\boldsymbol{B}$
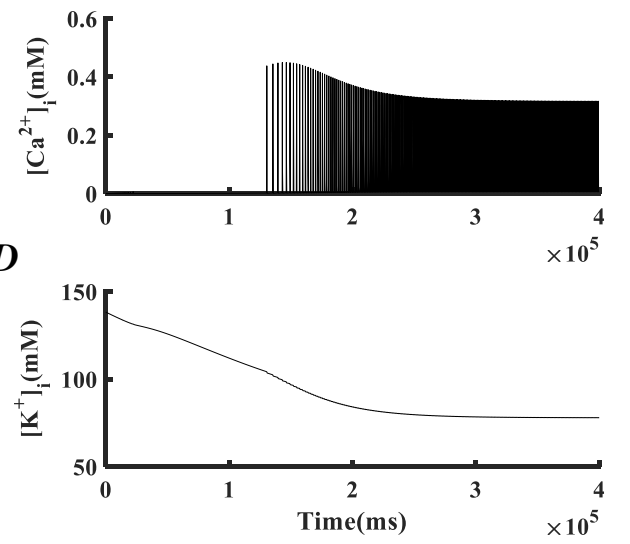

Figure 1. The action potential, $\left[\mathrm{Ca}^{2+}\right]_{i},\left[\mathrm{Na}^{+}\right]_{\mathrm{i}}$ and $\left[\mathrm{K}^{+}\right]_{\mathrm{i}}$ with time when $\mathrm{G}_{\mathrm{f}}=0.2 \mathrm{nS} / \mathrm{pF}$.

biological pacemakers. For producing a preferable pacing capacity, a hybrid therapy is used, by which cardiomyocytes differentiated from stem cells are often injected with pacing-related gene, especially $\mathrm{HCN}$ gene $[7$, 8]. These experiments proved the feasibility of producing pacemaker cells based on non-autorhythmic cells, especially VMs, by expressing $\mathrm{I}_{\mathrm{f}}$ current.

Although plenty of biological experiments have shown the necessity of expressing $\mathrm{I}_{\mathrm{f}}$ to induce autorhythm $[2,3,5]$ in VMs, the causal relationship between $\mathrm{I}_{\mathrm{f}}$ expression and pacing activity is not clear. Also, the mechanism responsible for $\mathrm{I}_{\mathrm{f}}$-induced spontaneous pacing activity is incompletely understood. In this study, we modified the ventricular single cell model (TP06 [9]) to simulate the autorhythm induced by expressing $I_{f}$ in VMs. An interesting phenomenon was an accumulation of intracellular calcium concentration $\left(\left[\mathrm{Ca}^{2+}\right]_{\mathrm{i}}\right)$ when incorporating $\mathrm{I}_{\mathrm{f}}$ into TP06 model. Meanwhile, the intracellular sodium and potassium concentration $\left(\left[\mathrm{Na}^{+}\right]_{\mathrm{i}}\right.$ and $\left[\mathrm{K}^{+}\right]_{\mathrm{i}}$ ) also changed. Our simulation shows that the amplitude of $I_{f}$ is a crucial factor that influence pacing ability. Finally, we demonstrated that a stable pacemaking cell model can be produced by clamping $\left[\mathrm{Na}^{+}\right]_{\mathrm{i}}$ and $\left[\mathrm{K}^{+}\right]_{\mathrm{i}}$.

\section{Methods}

Based on previous experiments [2, 3, 5], an autonomically responsive pacemaking function was produced by inclusion $\mathrm{I}_{\mathrm{f}}$ in the TP06 model. In the model, the electrophysiological behavior of a single cell is described by the following ordinary differential equation

$$
\frac{d V}{d t}=-\frac{I_{\text {ion }}}{C_{m}}
$$

where $V$ is voltage across cell membrane surfaces, $t$ time, $\mathrm{I}_{\mathrm{ion}}$ the sum of all transmembrane ionic currents, and $\mathrm{C}_{\mathrm{m}}$ cell capacitance.

$\mathrm{I}_{\mathrm{ion}}$ is given by the following equation

$$
\begin{aligned}
I_{i o n}= & I_{N a}+I_{K 1}+I_{t o}+I_{K r}+I_{K s}+I_{C a L}+I_{N a C a} \\
& +I_{N a K}+I_{p C a}+I_{p K}+I_{b C a}+I_{b N a}+I_{f}
\end{aligned}
$$

Particularly, the formulation of $\mathrm{I}_{\mathrm{f}}[10]$ is as follows

$$
\begin{aligned}
& I_{f}=I_{f, N a}+I_{f, K} \\
& I_{f, N a}=G_{f, N a} y\left(V-E_{N a}\right) \\
& I_{f, K}=G_{f, K} y\left(V-E_{K}\right)
\end{aligned}
$$

Where $\mathrm{G}_{\mathrm{f}, \mathrm{Na}}$ and $\mathrm{G}_{\mathrm{f}, \mathrm{K}}$ are maximal $\mathrm{I}_{\mathrm{f}, \mathrm{Na}}$ and $\mathrm{I}_{\mathrm{f}, \mathrm{K}}$ channel conductance, $\mathrm{y}$ is a time-independent inward rectification factor that is a function of voltage, $\mathrm{E}_{\mathrm{Na}}, \mathrm{E}_{\mathrm{K}}$ are equilibrium potentials of $\mathrm{Na}^{+}$and $\mathrm{K}^{+}$channels respectively. In our simulation, $G_{f, N a}$ and $G_{f, K}$ share a same value, which is defined as $\mathrm{G}_{\mathrm{f}}$.

Formulations for other channel currents of $\mathrm{I}_{\text {ion }}$ are listed in ref. 9.

\section{Results}

\subsection{Variations in intracellular ionic dynamics while incorporating $I_{f}$}

Automatic pacing activity in the TP06 model after incorporation of $I_{f}$ with $G_{f}=0.2 \mathrm{nS} / \mathrm{pF}$ as shown in Fig 1 . The pacemaking action potential reached a steady state after $200 \mathrm{~s}$ (Fig. 1A). However, the cycle length (CL) was too long for potential clinical applications (2236 ms vs $1000 \mathrm{~ms}$ in normal human VMs). Note that during the first $100 \mathrm{~s}$, the pacemaking action potential terminated after 26 pacing cycles, which was caused by drafting in the intracellular calcium concentration $\left(\left[\mathrm{Ca}^{2+}\right]_{\mathrm{i}}\right)$, as well as $\mathrm{Na}^{+}$ and $\mathrm{K}^{+}$concentrations. After $130 \mathrm{~s}$, spontaneous activity resumed and gradually became stable.

Remarkably, $\left[\mathrm{Ca}^{2+}\right]_{i}$ showed a step-wise change (Fig.1 B), which could be explained by the altered calcium dynamics induced by adding $\mathrm{I}_{\mathrm{f}}$. Calcium pumps in the 
membrane of the sarcoplasmic reticulum (SR) ( $\left.\mathrm{I}_{\text {up }}\right)$ remained a high value for a long time, pumping excess calcium into the SR. Especially in silent duration, the $\mathrm{Ca}^{2+}$ in SR gradually accumulated. When resuming pacing activity, ryanodine receptors sensed this elevation of calcium in the SR and responded with a sudden increased release of calcium from the SR ( $\left.\mathrm{I}_{\mathrm{rel}}\right)$. Through diffusion $\left(I_{x f e r}\right)$, the increased calcium released in the subspace travels to the cytoplasm. All of these contributed to a sudden influx of calcium ions into cytoplasm.

Except $\left[\mathrm{Ca}^{2+}\right]_{\mathrm{i}}$, other ionic concentration dynamics were also changed. Under the effect of $\mathrm{I}_{\mathrm{f}}, \mathrm{I}_{\mathrm{NaCa}}$ presented a substantial rise, which resulted in an increase of $\left[\mathrm{Na}^{+}\right]_{\mathrm{i}}$ to 6.3 times bigger than the normal value in VMs $(10.56 \mathrm{mM})$. At the same time, a rise of slow delayed rectifier current $\left(\mathrm{I}_{\mathrm{Ks}}\right)$ and inward-rectifier potassium current $\left(\mathrm{I}_{\mathrm{K} 1}\right)$ as well as a soar of transient outward current $\left(\mathrm{I}_{\mathrm{to}}\right)$ resulted a decrease of $\left[\mathrm{K}^{+}\right]_{\mathrm{i}}$ to $\sim 60 \%$ of the normal value in VMs $(134.8 \mathrm{mM})$. The changes of $\left[\mathrm{Na}^{+}\right]_{\mathrm{i}}$ and $\left[\mathrm{K}^{+}\right]_{\mathrm{i}}$ with time are shown in Fig. $1 \mathrm{C}$ and $\mathrm{D}$.
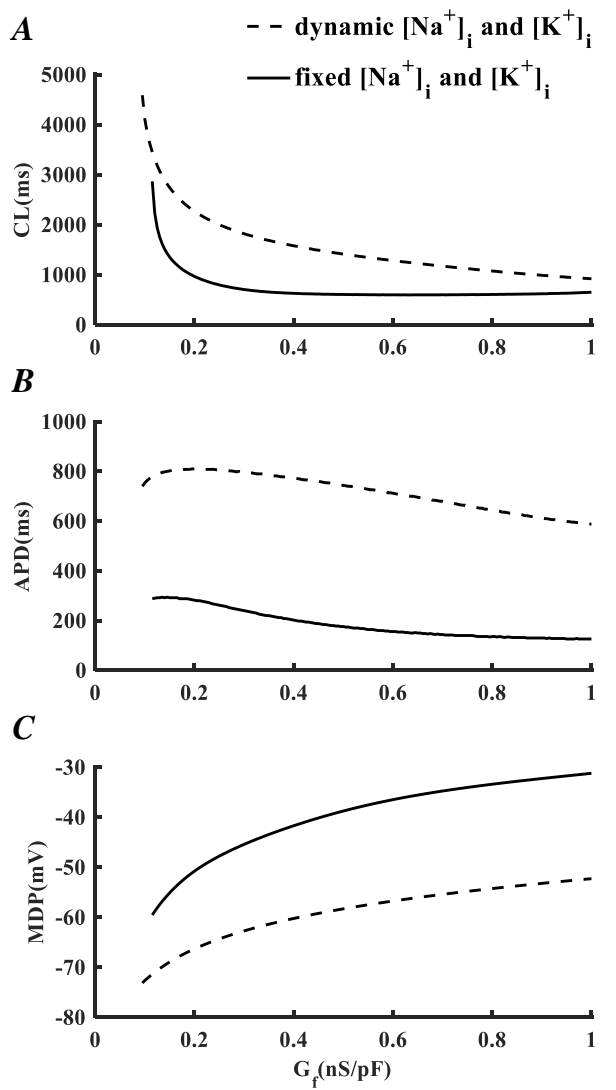

Figure 2. Measured CL, APD, MDP after stable solution (pacemaking cycle $n=1500$ ) with the change of $G_{f}$ under dynamic $\left[\mathrm{Na}^{+}\right]_{\mathrm{i}}$ and $\left[\mathrm{K}^{+}\right]_{\mathrm{i}}$ (dotted line) and fixed $\left[\mathrm{Na}^{+}\right]_{\mathrm{i}}$ and $\left[\mathrm{K}^{+}\right]_{\mathrm{i}}$ (solid line). $\mathrm{G}_{\mathrm{f}}$ is from $0 \mathrm{nS} / \mathrm{pF}$ to $1.0 \mathrm{nS} / \mathrm{pF}$ with $0.005 \mathrm{nS} / \mathrm{pF}$ increments. Under dynamic $\left[\mathrm{Na}^{+}\right]_{\mathrm{i}}$ and $\left[\mathrm{K}^{+}\right]_{\mathrm{i}}$, when $\mathrm{G}_{\mathrm{f}}<0.09 \mathrm{nS} / \mathrm{pF}$, no auto rhythm presents. Under fixed $\left[\mathrm{Na}^{+}\right]_{\mathrm{i}}$ and $\left[\mathrm{K}^{+}\right]_{\mathrm{i}}$, when $\mathrm{G}_{\mathrm{f}}<0.11 \mathrm{nS} / \mathrm{pF}$, no auto rhythm presents.

\subsection{Effect of If density on pacing ability}

In simulations, $G_{f}$ was changed systematically to investigate the effect of $\mathrm{I}_{\mathrm{f}}$ amplitude on pacing ability. The value of $\mathrm{G}_{\mathrm{f}}$ was changed from $0 \mathrm{nS} / \mathrm{pF}$ to $1.0 \mathrm{nS} / \mathrm{pF}$ with a $0.005 \mathrm{nS} / \mathrm{pF}$ increment. When $\mathrm{G}_{\mathrm{f}}<0.09 \mathrm{nS} / \mathrm{pF}$, autorhythm could not be induced in VMs. When $\mathrm{G}_{\mathrm{f}} \geqslant 0.09 \mathrm{nS} / \mathrm{pF}$, spontaneous rhythms showed in VMs model, which indicated the threshold of expressing $\mathrm{I}_{\mathrm{f}}$ to produce a biopacemaker. Variations of characteristics of action potential with the change of $\mathrm{G}_{\mathrm{f}}$ are shown in Fig. 2 (dotted line). With the rise of $\mathrm{G}_{\mathrm{f}}$, the $\mathrm{CL}$ gradually decreased and reached at approximately $1000 \mathrm{~ms}$, while the action potential duration (APD) was almost linearly declining. As expected, the maximum diastolic potential (MDP) became more positive with the increase of $G_{f}$ as massive $I_{f}$ increased the automatic depolarization in phase 4 , leading to a more positive MDP.

\subsection{An optimized If-induced pacemaker by fixing $\left[\mathrm{Na}^{+}\right]_{i}$ and $\left[\mathrm{K}^{+}\right]_{\mathrm{i}}$}

As shown in above, the long CL was caused by the dramatically altered $\left[\mathrm{Na}^{+}\right]_{\mathrm{i}}$ and $\left[\mathrm{K}^{+}\right]_{\mathrm{i}}$. Further simulations were conducted by clamping $\left[\mathrm{Na}^{+}\right]_{\mathrm{i}}$ and $\left[\mathrm{K}^{+}\right]_{\mathrm{i}}$ to their original values (7.67 and $138.3 \mathrm{mM}$ respectively [9]). Results are shown in Fig. 3, demonstrating a considerably improved pacing ability of pacemaker (Fig. 3, solid line). With $\mathrm{G}_{\mathrm{f}}=0.2 \mathrm{nS} / \mathrm{pF}$, compared to dynamic $\left[\mathrm{Na}^{+}\right]_{\mathrm{i}}$ and $\left[\mathrm{K}^{+}\right]_{\mathrm{i}}$, the pacing activity reached a stable state more quickly. The CL and APD declined considerably (942 ms vs $2238 \mathrm{~ms}$, and $290 \mathrm{~ms}$ vs $884 \mathrm{~ms}$ ), and MDP was more positive ($50.44 \mathrm{mV}$ vs $-66.09 \mathrm{mV}$ ), suggesting the pacemaker was easier to depolarize (Fig. 3B, C, D). This was because the controlled $\left[\mathrm{Na}^{+}\right]_{\mathrm{i}}$ and $\left[\mathrm{K}^{+}\right]_{\mathrm{i}}$ suppressed the Na-K pump current $\left(\mathrm{I}_{\mathrm{NaK}}\right)$, making depolarization easier, thus showing a stronger pacing ability.

Furthermore, we simulated the membrane potential with fixed $\left[\mathrm{Na}^{+}\right]_{i}$ and $\left[\mathrm{K}^{+}\right]_{i}$ when the value of $\mathrm{G}_{\mathrm{f}}$ was changing from $0 \mathrm{nS} / \mathrm{pF}$ to $1.0 \mathrm{nS} / \mathrm{pF}$ with $0.005 \mathrm{nS} / \mathrm{pF}$ increments. The CL, APD, and MDP with the change of $\mathrm{G}_{\mathrm{f}}$ are shown in Fig. 2 (solid line). When $\left[\mathrm{Na}^{+}\right]_{\mathrm{i}}$ and $\left[\mathrm{K}^{+}\right]_{\mathrm{i}}$ were fixed, the tendency of CL, APD, and MDP variations was similar to that under dynamic $\left[\mathrm{Na}^{+}\right]_{\mathrm{i}}$ and $\left[\mathrm{K}^{+}\right]_{\mathrm{i}}$, but the $\mathrm{CL}$ and APD was considerably shorter and the MDP was more positive, which meant a superior and robust pacing activity.

\section{Conclusion}

In this study, we simulated the automaticity induced by expressing $\mathrm{I}_{\mathrm{f}}$ in $\mathrm{VMs}$ and demonstrated that overexpressing $\mathrm{I}_{\mathrm{f}}$ could induce spontaneous beatings in a model of VMs. In the VMs model, after reaching the threshold of $\mathrm{I}_{\mathrm{f}}$, automaticity could be induced and the action potential became stable after a period. 


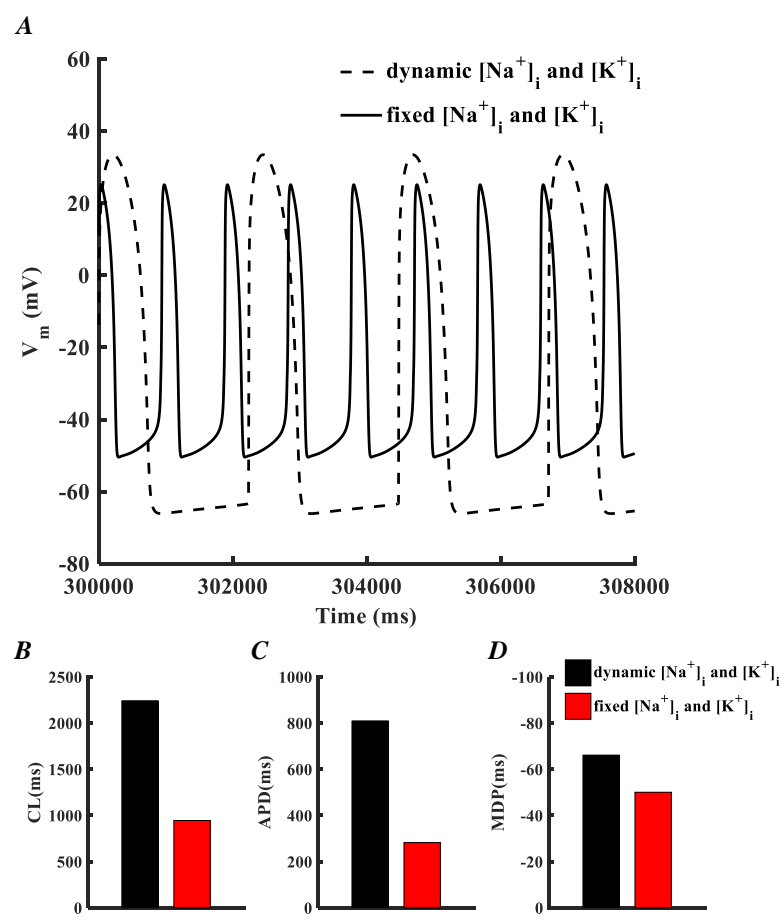

Figure 3. A: The action potential with time when $\mathrm{G}_{\mathrm{f}}=0.2$ $\mathrm{nS} / \mathrm{pF}$ under dynamic and fixed $\left[\mathrm{Na}^{+}\right]_{\mathrm{i}}$ and $\left[\mathrm{K}^{+}\right]_{\mathrm{i}}$. B: The CL in Fig. A. C: The APD in Fig. A. C: The MDP in Fig. A.

However, automaticity due to the action of $\mathrm{I}_{\mathrm{f}}$ in VMs changed intracellular ionic dynamics, especially the accumulation of $\left[\mathrm{Ca}^{2+}\right]_{\mathrm{i}}$. Meanwhile, accumulation of $\left[\mathrm{Na}^{+}\right]_{\mathrm{i}}$ and a decrease of $\left[\mathrm{K}^{+}\right]_{\mathrm{i}}$ were also observed which led to a long CL. After clamping $\left[\mathrm{Na}^{+}\right]_{\mathrm{i}}$ and $\left[\mathrm{K}^{+}\right]_{\mathrm{i}}$ to original value, an improved biopacemaker was produced. In conclusion, these simulation results support the possibility of producing pacemakers based on VMs by overexpressing $I_{f}$. Possible effect of $I_{f}$ amplitude on spontaneous beatings was also investigated. This study provides insights into understandings of biological pacemaker.

\section{Acknowledgements}

The work is supported by the National Natural Science Foundation of China (NSFC) under Grant nos.61572152, 61601143, 61571165 and 81770328, the Science Technology and Innovation Commission of Shenzhen Municipality under Grant nos. JSGG20160229125049615 and JCYJ20151029173639477, and Heilongiiang and China Postdoctoral Science Foundation under Grant nos.2015M581448.

\section{References}

[1] Rosen MR. Gene therapy and biological pacing. New Engl J Med 2014;371:1158-1159.

[2] Qu JH, Plotnikov AN, Danilo P, Shlapakova I, Cohen IS, Robinson RB, Rosen MR. Expression and function of a biological pacemaker in canine heart. Circulation 2003;107:1106-1109.

[3] Plotnikov AN, Sosunov EA, Qu JH, Shlapakova IN, Anyukhovsky EP, Liu LL, Janse MJ, Brink PR, Cohen IS, Robinson RB, Danilo P, Rosen MR. Biological pacemaker implanted in canine left bundle branch provides ventricular escape rhythms that have physiologically acceptable rates. Circulation 2004;109:506-512.

[4] Valiunas V, Kanaporis G, Valiuniene L, Gordon C, Wang HZ, Li L, Robinson RB, Rosen MR, Cohen IS, Brink PR. Coupling an hen2-expressing cell to a myocyte creates a two-cell pacing unit. J Physiol-London 2009;587:5211-5226.

[5] Hu YF, Dawkins JF, Cho HC, Marban E, Cingolani E. Biological pacemaker created by minimally invasive somatic reprogramming in pigs with complete heart block. Sci Transl Med 2014;6

[6] Kehat I, Kenyagin-Karsenti D, Snir M, Segev H, Amit M, Gepstein A, Livne E, Binah O, Itskovitz-Eldor J, Gepstein L. Human embryonic stem cells can differentiate into myocytes with structural and functional properties of cardiomyocytes. J Clin Invest 2001;108:407-414.

[7] Potapova I, Plotnikov A, Lu ZJ, Danilo P, Valiunas V, Qu JH, Doronin S, Zuckerman J, Shlapakova IN, Gao JY, Pan ZM, Herron AJ, Robinson RB, Brink PR, Rosen MR, Cohen IS. Human mesenchymal stem cells as a gene delivery system to create cardiac pacemakers. Circ Res 2004;94:952959.

[8] Yang J, Song T, Wu P, Chen YJ, Fan XR, Chen H, Zhang J, Huang CX. Differentiation potential of human mesenchymal stem cells derived from adipose tissue and bone marrow to sinus node-like cells. Mol Med Rep 2012;5:108-113.

[9] ten Tusscher KH, Panfilov AV. Alternans and spiral breakup in a human ventricular tissue model. American journal of physiology. Heart and circulatory physiology 2006;291:H1088-1100.

[10] Zhang H, Holden AV, Kodama I, Honjo H, Lei M, Varghese T, Boyett MR. Mathematical models of action potentials in the periphery and center of the rabbit sinoatrial node. American journal of physiology. Heart and circulatory physiology 2000;279:H397-421.

Address for correspondence.

Henggui Zhang

Room 3.07, Shuster building

Manchester, M13 9PL, UK

henggui.zhang@manchester.ac.uk 